\title{
Strategy and early results of treatment of advanced cervical cancer patients with synchronous cancers observed in PET-CT imaging
}

\author{
Michał Płachta ${ }^{1}$, Witold Cholewińskii, ${ }^{3}$, Ewa Burchardt ${ }^{1}$, Paulina Cegła ${ }^{2}$, Bartosz Urbański ${ }^{1}$, \\ Żaneta Wareńczak-Florczak ${ }^{1,3}$, Andrzej Roszak ${ }^{1,3}$ \\ ${ }^{1}$ Department of Radiotherapy and Oncological Gynecology, Greater Poland Cancer Center, Poznan, Poland \\ ${ }^{2}$ Department of Nuclear Medicine, Greater Poland Cancer Center, Poznan, Poland \\ ${ }^{3}$ Department of Electroradiology, Poznan University of Medical Sciences, Poznan, Poland
}

\begin{abstract}
Objectives: The aim of this study was to present strategy and early results of treatment of advanced cervical cancer patients with synchronous cancers observed in PET-CT imaging, treated at the Greater Poland Cancer Center.

Material and methods: The study included a group of 200 patients with diagnosed stage IIB-IIIB cervical cancer who received PET-CT for the purpose of radiotherapy treatment planning.

Results: Among our study group, four patients (2\%) were found to have a synchronous cancer. Two of the cases were diagnosed as breast cancer. However, cancers diagnosed in the other two patients were head and neck malignancies - hypopharyngeal and laryngeal cancer. The choice of an optimal therapeutic approach requires taking into account characteristics of particular malignancies, their stage and histopathology. The whole therapy included radiotherapy of cervical cancer with various combinations of systemic treatment, radiotherapy or surgery of synchronous cancer. According to treatment results, patients diagnosed with breast cancer and hypopharyngeal cancer achieved complete remission of both primary and secondary tumour. Patient diagnosed with laryngeal malignancy, despite achieving complete remission of cervical cancer, finished radiotherapy of the synchronous cancer at a palliative dose.

Conclusions: The growing availability of PET-CT and other imaging methods in cancer diagnosis will increase the number of diagnosed synchronous cancers. Second primary cancers are often detected at an early stage, where radical treatment can be performed for both primary and secondary tumour. However, treatment of such complicated clinical cases as synchronous cancers should be carried out by multidisciplinary teams.
\end{abstract}

Key words: cervical cancer, synchronous cancer, second primary cancer, PET-CT

Ginekologia Polska 2017; 88, 9: 475-480

\section{INTRODUCTION}

Second Primary Cancers (SPCs) are new, primary independent cancer foci. Timeframes that allow to categorize them into synchronous and metachronous cancers differ depending on authors. The SEER (Surveillance, Epidemiology, and End Results) register held by the U.S. National Cancer Institute ( $\mathrm{NCl})$ defines synchronous cancer as a second focus diagnosed within two months of the primary malignancy [1]. Further independent tumour foci diagnosed after that time are referred to as metachronous cancers. The International Agency for Research on Cancer sets the border line between synchronous and metachronous cancer at six months [2]. This study assumes the period of two months as a timeframe for synchronous cancer diagnosis.

Diagnosis of synchronous cancer is closely associated with thorough interview and physical examination as well as the use of additional diagnostic tests. Of particular importance for determining the clinical stage of the tumour 
are Computed Tomography (CT) and Magnetic Resonance Imaging (MRI). Increasingly, Positron Emission Tomography (PET-CT) is also performed where fluorodeoxyglucose-based metabolic activity assessment allows to detect a primary focus, metastatic foci as well as other neoplasms.

At the Greater Poland Cancer Center, PET-CT scans are performed in patients, treated with radical radiochemotherapy or radiotherapy for advanced cancer of the cervix, for the purpose of optimalisation radiotherapy treatment planning. In over $35 \%$ of the patients, the stage of the disease as determined by the PET-CT imaging was significantly different from that found in clinical examination, which led to restaging of the disease and change of the planned therapeutic approach by including systemic treatment in various combinations with radiotherapy.

\section{OBJECTIVES}

The aim of this study was to present strategy and early results of treatment of advanced cervical cancer patients diagnosed with synchronous cancers in PET-CT imaging, treated at the Greater Poland Cancer Center.

\section{MATERIAL AND METHODS}

The study conducted in 2011-2015 included a group of 200 patients with diagnosed stage IIB-IIIB cervical cancer who received PET-CT. The examination employed a hybrid scanner comprising a PET and transmission CT scanner (Gemini TF). The acquisition was made 60 minutes after intravenous injection of $300 \mathrm{MBq}$ 18-fluorodeoxyglucose in patients who had had an empty stomach for at least 5 hours. The injection was preceded by the evaluation of glucose concentration in blood serum which could not exceed $8.33 \mathrm{mmol} / \mathrm{L}$ (150 mg/dL) during the examination. The acquisition was performed from the skullcap to the mid-thighs with CT (120 keV, $50 \mathrm{mAs}$ ) followed by PET $(100 \mathrm{sec} . / 9 \mathrm{~cm}$ body section). Data obtained were reconstructed based on iterative techniques using the time-of-flight technology to receive cross-sections in the three standard planes. To evaluate the pathological changes, the metabolic activity of the changes was assessed based on the SUVmax value.

In our study group, four patients (2\%) were found to have a synchronous cancer which was confirmed histopathologically. Each of the four patients was found to have carcinoma of the cervix in stage IIIB according to the International Federation of Gynecology and Obstetrics (FIGO). Two of the cases were diagnosed as early stage breast cancer, confirmed in mammography. In Poland, the most common cancer locations in women are, in descending order, breast, lungs and endometrium [3]. However, the other two patients with diagnosed synchronous tumours had head and neck cancers which account for a low proportion of all diagnosed malignancies in women (approx. 1.4\%) [3]. In one of them, the stage of the $\mathrm{H} \& \mathrm{~N}$ cancer excluded surgery, while the other patient refused the proposed surgery and chose radiotherapy instead. Patient characteristics are shown in Table 1.

In addition to the above mentioned four cases, one of the 200 patients studied, with diagnosed stage IIB cervical cancer, was treated for invasive cancer of the left breast. Metastatic lesions in the lungs were found by PET. The changes in the PET image, stage of primary breast cancer and molecular subtype indicated that the lesions had originated from the previously treated cancer of the left breast. This conclusion is also supported by the fact that the patient, following breast cancer surgery, did not undergo the planned adjuvant chemotherapy and radiotherapy due to the detection of cancer of the cervix. No biopsy of the metastatic lesions was performed.

Another patient had pancreatic cancer, treated palliatively by stenting of biliary ducts, diagnosed within six months preceding the cervical cancer treatment. PET imaging confirmed the existence of an active neoplastic process within the head of pancreas, metastatic lymph nodes and metastatic foci in the bones. According to some studies and data sets, such a time interval would also allow those two processes to be classified as synchronous cancers.

The characteristics of the patients are shown in Table 2 .

Table 1. Characteristics of synchronous cancer patients

\begin{tabular}{|c|c|c|c|c|c|}
\hline No. & Age & $\begin{array}{c}\text { Stage of cervical } \\
\text { cancer }\end{array}$ & $\begin{array}{r}\text { Histopathology } \\
\text { of cervical cancer }\end{array}$ & $\begin{array}{r}\text { Synchronous cancer } \\
\text { and stage }\end{array}$ & Histopathology of synchronous cancer \\
\hline 1 & 66 & IIIB & $\begin{array}{c}\text { Carcinoma planoepitheliale } \\
\text { microcellulare akeratodes }\end{array}$ & $\begin{array}{r}\text { Cancer of the left breast, } \\
\text { pT1c, pNO(sn) }\end{array}$ & $\begin{array}{r}\text { Invasive breast cancer (NST/ductal with } \\
\text { features of cribriform and tubular pattern) } \\
\text { NHG1; ER(+), PgR(+), HER2(-) }\end{array}$ \\
\hline 2 & 63 & IIIB & $\begin{array}{r}\text { Carcinoma planoepitheliale } \\
\text { akeratodes G2 }\end{array}$ & $\begin{array}{r}\text { Cancer of the left breast, } \\
\text { pT1c, pN1a }\end{array}$ & $\begin{array}{r}\text { Invasive breast cancer (NST) NHG1; ER(+), } \\
\text { PgR(+), HER2(-) }\end{array}$ \\
\hline 3 & 69 & IIIB & $\begin{array}{r}\text { Carcinoma male differentiatum } \\
\text { colli uteri G3 }\end{array}$ & $\begin{array}{r}\text { Hypopharyngeal cancer, } \\
\text { T4bN2cM0 }\end{array}$ & $\begin{array}{r}\text { Non-keratinising squamous cell } \\
\text { carcinoma G2 }\end{array}$ \\
\hline 4 & 61 & IIIB & $\begin{array}{r}\text { Carcinoma planoepitheliale } \\
\text { non keratodes G3 }\end{array}$ & $\begin{array}{r}\text { Laryngeal cancer, } \\
\text { T2N2bM0 }\end{array}$ & $\begin{array}{r}\text { Non-keratinising squamous cell } \\
\text { carcinoma G3 }\end{array}$ \\
\hline
\end{tabular}


Table 2. Characteristics of patients with cervical cancer and other previously diagnosed cancer

\begin{tabular}{|c|c|c|c|c|c|}
\hline No. & Age & $\begin{array}{l}\text { Stage of } \\
\text { cervical cancer }\end{array}$ & $\begin{array}{l}\text { Histopathology } \\
\text { of cervical cancer }\end{array}$ & $\begin{array}{l}\text { Second cancer: primary } \\
\text { stage and histopathology }\end{array}$ & $\begin{array}{c}\text { Second cancer: clinical status } \\
\text { at PET test }\end{array}$ \\
\hline 5 & 51 & IIB & $\begin{array}{l}\text { Carcinoma planoepitheliale } \\
\text { typus keratodes }\end{array}$ & $\begin{array}{c}\text { Invasive cancer of the left } \\
\text { breast (ductal type) } \\
\mathrm{NHG} 2, \mathrm{pT} 2, \mathrm{pNO}(\mathrm{sn}) ; \\
\mathrm{ER}(+), \operatorname{PgR}(+), \mathrm{HER} 2(+++)\end{array}$ & $\begin{array}{c}\text { Metastases of the left breast cancer to } \\
\text { the lungs }\end{array}$ \\
\hline 6 & 36 & IIIB & $\begin{array}{c}\text { Carcinoma neuroendocervicale } \\
\text { microcellulare }\end{array}$ & $\begin{array}{l}\text { Pancreatic cancer T4 N1 M1; } \\
\text { Cellulae carcinomatosae } \\
\text { (fine needle biopsy) }\end{array}$ & $\begin{array}{l}\text { Persistent infiltration within the head of } \\
\text { pancreas, metastatic lymph nodes and } \\
\text { distant metastases to the skeletal system }\end{array}$ \\
\hline
\end{tabular}

\section{Treatment}

The choice of an optimal therapeutic strategy requires characteristics of particular malignancies to be taken into account, including their stage and histopathology. In the case of the above discussed patients, each decision on what diagnostic and therapeutic approach to take was made by a multidisciplinary team (MDT) of gynaecological oncologists, clinical oncologists and radiation oncologists. The treatment took into account the occurrence of two cancers, which required that a parallel therapy be used to cover both of them.

A detailed protocols applied in the patients and particular stages in the treatment of the primary cancer and synchronous cancers are shown in Table 3.

\section{Patient 1}

In the case of the first patient analysed, PET-CT showed a metabolically active tumour of the cervix and body of the uterus with features of a proliferative process and metastases to the iliac and paraaortic lymph nodes and a nodule in the left breast with features of a malignant process. In mammography, the nodule was evaluated as BIRADS 5. Breast cancer was confirmed in a fine needle aspiration biopsy (FNAB). Due to the advanced stage of cervical cancer (IIIB), metastases to the paraaortic lymph nodes and the co-occurrence of a second cancer, the patient received, at the first stage, an independent systemic treatment, i.e. neoadjuvant chemotherapy. It involved cytostatics adequate for the treatment of both breast cancer and cervical cancer. Then, quadrantectomy was performed with a sentinel node biopsy (SNB). After two weeks, a radical radiotherapy was performed targeted against the tumour of the cervix - teleradiotherapy, brachytherapy and hyperthermia. Then, the patient was treated with adjuvant radiotherapy for breast cancer. Further treatment involved adjuvant hormonal therapy.

\section{Patient 2}

PET-CT of the next patient showed a metabolically active proliferation in the cervix uteri with features of proliferative process and without features of spread. The patient began a radical radiotherapy due to diagnosed advanced cancer of the cervix (IIIB). It involved tele- and brachytherapy and weekly administrations of cisplatin. Due to a poor tolerance to chemotherapy, cytostatic treatment was terminated after the administration of the first cycle of cisplatin. The

Table 3. Stages and methods of treatment of synchronous cancer patients

\begin{tabular}{|c|c|c|c|c|c|c|}
\hline No. & Age & Treatment stage I & Treatment stage II & Treatment stage III & Treatment stage IV & Treatment stage V \\
\hline 1 & 66 & $\begin{array}{l}\text { Neoadjuvant chemotherapy } \\
\text { (paclitaxel + cisplatin; } \\
6 \text { courses) }\end{array}$ & $\begin{array}{l}\text { Breast conserving } \\
\text { surgery (BCS) with } \\
\text { sentinel node biopsy } \\
\text { (SNB) }\end{array}$ & $\begin{array}{l}\text { Radical radiotherapy } \\
\text { for cervical } \\
\text { cancer + } 2 \text { hyperthermia } \\
\text { procedures }\end{array}$ & $\begin{array}{l}\text { Adjuvant breast } \\
\text { cancer radiotherapy }\end{array}$ & $\begin{array}{l}\text { Adjuvant hormonal } \\
\text { therapy (in progress) }\end{array}$ \\
\hline 2 & 63 & $\begin{array}{c}\text { Radical radiochemotherapy } \\
\text { for cervical cancer (cisplatin; } \\
1 \text { course) }+2 \text { hyperthermia } \\
\text { procedures }\end{array}$ & $\begin{array}{l}\text { Breast conserving } \\
\text { surgery with axillary } \\
\text { lymph node dissection }\end{array}$ & $\begin{array}{l}\text { Adjuvant breast cancer } \\
\text { radiotherapy }\end{array}$ & $\begin{array}{l}\text { Adjuvant hormonal } \\
\text { therapy (in } \\
\text { progress) }\end{array}$ & \\
\hline 3 & 69 & $\begin{array}{l}\text { Radical radiotherapy for } \\
\text { cervical cancer }\end{array}$ & $\begin{array}{l}\text { Palliative radiotherapy } \\
\text { for hypopharyngeal } \\
\text { cancer }\end{array}$ & & & \\
\hline 4 & 61 & $\begin{array}{c}\text { Radical radiotherapy } \\
\text { for cervical cancer with } \\
\text { simultaneous chemotherapy } \\
\text { (paclitaxel + cisplatin; } \\
3 \text { courses at 4-week intervals) }\end{array}$ & $\begin{array}{l}\text { Radical radiotherapy for } \\
\text { laryngeal cancer }\end{array}$ & & & \\
\hline
\end{tabular}


Table 4. Stages and methods of treatment of patients with other previously diagnosed cancer

\begin{tabular}{|c|c|c|c|c|c|}
\hline No. & Age & Treatment stage I & Treatment stage II & Treatment stage III & Treatment stage IV \\
\hline 5 & 51 & $\begin{array}{c}\text { Radical radiotherapy for } \\
\text { cervical cancer }\end{array}$ & $\begin{array}{c}\text { Chemotherapy of metastatic } \\
\text { lesions: TAC ( } 6 \text { courses), } \\
\text { herceptin and capecitabine } \\
\text { ( } 9 \text { courses) }\end{array}$ & $\begin{array}{l}\text { Palliative radiotherapy for } \\
\text { brain metastasis }\end{array}$ & $\begin{array}{c}\text { Chemotherapy continuation: } \\
\text { gemcitabine and carboplatin } \\
\text { (18 courses), vinorelbine (in } \\
\text { progress) }\end{array}$ \\
\hline 6 & 36 & $\begin{array}{c}\text { Chemotherapy involving } \\
\text { etoposide and cisplatin } \\
\text { (7 courses) }\end{array}$ & $\begin{array}{l}\text { Palliative radiotherapy for } \\
\text { cervical cancer }\end{array}$ & & \\
\hline
\end{tabular}

treatment was completed with radiotherapy plus hyperthermia. Mammography was performed during radiation therapy to reveal a lesion in the right breast - BIRADS 5. Core needle biopsy confirmed the diagnosis of breast cancer. The lesion was not visible in the previously performed PET-CT imaging. After completion of cervical cancer treatment, quadrantectomy was carried out with a left axillary lymph node dissection. Then, adjuvant radiotherapy for breast cancer was performed. Further treatment involved adjuvant hormonal therapy.

\section{Patient 3}

The changes observed in PET-CT imaging in the third patient involved a proliferation in the cervix with features of a malignant process and hypermetabolic infiltration of the posterior wall of the hypopharynx with features indicating a second focus of a primary malignant process with metastases to the left cervical lymph nodes. Biopsy of the lesion confirmed the diagnosis of squamous cell carcinoma. Due to obstructive nephropathy and emergent unilateral nephrostomy, a decision was made to refrain from a combined systemic treatment. The patient was qualified for a stand-alone radical cervical cancer radiotherapy. When the therapy was finished, the patient was qualified for radical radiotherapy of the detected synchronous cancer because of the advanced stage of her pharyngeal cancer. During hospitalisation, accumulation of fluid in the pleural cavity was observed. Cytology of the fluid confirmed the presence of cancer cells. It was impossible to clearly determine the origin of the metastasis to the pleura. Therefore, radiotherapy of the hypopharynx was finished at a palliative dose (36 Gy). The patient was discharged from hospital with recommendation for palliative care at home. According to the information obtained, the patient died two months after the completion of palliative radiotherapy.

\section{Patient 4}

A pre-treatment PET-CT performed in the fourth patient showed a metabolically active cervical tumour with features of a malignant process and metastases to iliac lymph nodes. Furthermore, a metabolically active infiltration of the larynx was found with features of a second focus of the primary proliferative process with metastases to the left cervical lymph nodes. The stage of cancer was assessed in $\mathrm{CT}$. In biopsy, fragments of laryngeal squamous mucosa were found with reactive changes, without dysplasia. The patient started a radical radiotherapy for cancer of the cervix. As clinical symptoms persisted (chronic hoarse voice), another biopsy of the tumour was performed. It confirmed the diagnosis of laryngeal squamous cell carcinoma. A systemic treatment was started. The cytostatics used acted against both cervical and laryngeal cancer. Following the treatment, a total laryngectomy was proposed. The patient refused to be operated and, therefore, was subjected to a stand-alone radical radiotherapy for laryngeal carcinoma using the tomotherapy technique.

Particular treatment stages of the above discussed two patients with previously diagnosed cancer are shown in Table 4.

\section{Patient 5}

In the other study group, PET-CT performed in the above discussed patient indicated a hypermetabolic infiltration of the cervix with metastases to external iliac lymph nodes and metabolically active nodules in both lungs with features of metastasis, probably from breast cancer. A decision was taken to conduct a radical radiotherapy for tumour of the cervix involving tele- and brachytherapy. Then, patient received chemotherapy in order to treat the metastatic lesions. After the completion of the first line chemotherapy, a chest $C T$ showed the progression of the disease. Hormonal therapy was changed from tamoxifen to aromatase inhibitor. A follow-up PET scan revealed a complete metabolic response to the treatment of cervical tumour and metastatic lymph nodes in the abdominal cavity and a partial metabolic response to the treatment of nodular lesions in both lungs. The patient started second line chemotherapy. The next chest CT indicated the progression of pulmonary lesions. Additionally, MRI revealed metastases to the brain. The patient received a palliative radiotherapy for metastatic cerebral lesions. A decision was made to apply a third line chemotherapy. The systemic treatment regimen was changed due to pancytopenia. Currently, the patient is undergoing her fourth line systemic treatment. 
Table 5. Treatment results for patients studied

\begin{tabular}{|c|c|c|c|c|}
\hline No. & Cancer type & Result after treatment & $\begin{array}{l}\text { Duration of follow-up } \\
\text { (as of Jan. 2017) [months] }\end{array}$ & Result after follow-up \\
\hline \multirow{2}{*}{1} & Cervical cancer & Complete remission & 20 & Complete remission \\
\hline & Breast cancer & Complete remission & 18 & Complete remission \\
\hline \multirow{2}{*}{2} & Cervical cancer & Complete remission & 32 & Complete remission \\
\hline & Breast cancer & Complete remission & 27 & Complete remission \\
\hline \multirow{2}{*}{3} & Cervical cancer & Complete remission & & \multirow{2}{*}{ Patient's death } \\
\hline & Hypopharyngeal cancer & Partial remission & & \\
\hline \multirow{2}{*}{4} & Cervical cancer & Complete remission & 12 & Complete remission \\
\hline & Laryngeal cancer & Complete remission & 9 & Complete remission \\
\hline \multirow[b]{2}{*}{5} & Cervical cancer & Complete remission & 45 & Complete remission \\
\hline & Breast cancer & Complete remission & 49 & $\begin{array}{l}\text { Progression - chemotherapy } \\
\text { in progress }\end{array}$ \\
\hline \multirow{2}{*}{6} & Cervical cancer & Partial remission & No data & No data \\
\hline & Pancreatic cancer & Progression & No data & No data \\
\hline
\end{tabular}

\section{Patient 6}

Imaging (ultrasound, CT) performed in the patient with diagnosed concurrent pancreatic cancer displayed massive lymph node lesions within the abdominal cavity. Chemotherapy was delivered. Follow-up PET revealed persisting lymph node lesions within the small pelvis and abdominal cavity, an active process in the head of pancreas and metastatic lesions in the bony structure. Palliative radiotherapy for cancer of the cervix was performed.

\section{RESULTS}

The result analysis of the treatment of the six patients is shown in Table 5.

\section{DISCUSSION}

Imaging methods, which are becoming increasingly common, allow a precise assessment of primary cancer stage and often detect synchronous cancers. In a study of Scottish epidemiologic registries, new cancers were found to develop in 5\% of 57,000 patients. Among those patients, synchronous cancer was diagnosed in $28 \%$ simultaneously or within two months. In that report, the most common malignancy, both primary and secondary, was lung cancer. Breast cancer was the third most common secondary cancer in all the study group [4].

In view of the increasing availability of PET-CT imaging in cancer diagnosis, synchronous neoplasms are more often detected. Ishimori et al. published a report on 1900 patients with diagnosed or suspected primary cancer who received PET-CT. In $1.2 \%$ of the patients, second primary cancers were found and confirmed by histopathology [5].

PET-CT tests used at the Greater Poland Cancer Center in inoperative cervical cancers for teleradiotherapy treatment planning indicated the occurrence of second primary cancers, which had not been detected before, in $2 \%$ of the patients. A Korean study conducted by Tong et al. related to the incidence of synchronous cancers in women with diagnosed with gynaecological cancer [6]. Out of 3,100 patients included, synchronous cancer was found in $0.63 \%$. The most common primary malignancy was cancer of the endometrium concurrent with ovarian cancer and cervical cancer. A Japanese study including 1,000 patients with gynaecological cancers reported the coexistence of a second primary cancer in $4.3 \%$ patients, of whom $38 \%$ had synchronous cancers. The most common secondary malignancy was breast cancer [7]. In a Turkish series including 4,000 women with primary gynaecological cancer, $1.3 \%$ were found to have synchronous or metasynchronous cancers. The most common concomitant cancers were those of the endometrium and ovary [8]. Other Turkish studies report that the most common concomitant primary cancers in women are breast cancer as a primary malignancy and gynaecological cancer as a second independent malignancy [9]. In the above presented report from the Greater Poland Cancer Center, advanced cervical cancer coexisted most often with breast cancer which is the most prevalent cancer in Polish women [2]. Additionally, head and neck cancers, i.e. hypopharyngeal and laryngeal carcinoma, were also found.

In the case of two or more synchronous tumours being diagnosed, it is of key importance to choose an appropriate treatment, particularly in the case of chemotherapy optimally targeted at both primary tumours. The sequence of treatments in particular synchronous cancers in the cases described was primarily adapted to therapeutic possibilities and clinical stage. The first patient received neoadjuvant systemic treatment. It comprised cytostatics used both in the treatment of cancer of the cervix and induction 
chemotherapy for breast cancer $[10,11]$. In the case of the fourth patient, systemic treatment was started parallel to cervical cancer radiotherapy. Notably, the chemotherapy regimen applied differed from the one commonly chosen (cisplatin - single dose of $40 \mathrm{mg} / \mathrm{m}^{2}$ at 7-day intervals). Instead, $135 \mathrm{mg} / \mathrm{m}^{2}$ paclitaxel was used in combination with $75 \mathrm{mg} / \mathrm{m}^{2}$ cisplatin at 4-week intervals. This approach was dictated by the concomitant synchronous laryngeal cancer whose treatment requires cisplatin [12].

That SEER-based study indicates that cervical cancer patients are at an increased risk of secondary cancers, mainly associated with cervical cancer risk factors. In women with HPV virus infection, these were mostly cancers of the vagina, vulva and anus. The above analysis of secondary cancer risk does not include the synchronous/metasynchronous division. The authors also took note of an increased risk of secondary cancers in patients treated with radiotherapy for cervical cancer [13]. Another study of the same register, this time in terms of synchronous malignancies only, showed them to be present in $1.96 \%$ of cancer patients. In over $88 \%$ of them, synchronous cancers were diagnosed at the same time as primary cancers [14].

Considering that synchronous cancers are often detected at early stage, it is possible to treat them radically [15-18]. The role of diagnostic and therapeutic interdisciplinary teams is paramount in this case. The integration of knowledge and experience of experts in various disciplines, in this case gynaecological oncology, clinical oncology, radiation oncology, radiology and pathomorphology, enables a fully comprehensive and personalised diagnostic and therapeutic process. Treatment protocols are prepared and adjusted to the needs of particular patients, which is of particular importance for synchronous cancers.

\section{CONCLUSIONS}

The growing availability of PET-CT and other imaging methods will surely increase the number of diagnosed synchronous cancers.

In the collected material, out of four synchronous cancers, two (50\%) were breast cancer cases. Interestingly, cancers diagnosed in the other two patients were head and neck malignancies which are relatively rare in the population of Polish women

A note should be taken that according to treatment results shown in Table 5, despite diagnosed synchronous cancer concomitant with advanced cervical cancer, complete remission of both malignancies was achieved in three patients. That was possible mainly because of early detection of the synchronous tumours, where radical and personalised treatment, targeted at both types of cancer, can be performed.
Treatment of such complicated clinical cases as synchronous cancers should be carried out at institutions that have multidisciplinary diagnostic and therapeutic teams to perform that kind of therapy. PET-CT seems to be a universal diagnostic method which, apart from determination of primary cancer stage, allows to identify the presence of a second cancer.

\section{REFERENCES}

1. Howe HL (ed). A Review of the Definition for Multiple Primary Cancers in the United States. Workshop Proceedings From December 4-6, 2002, in Princeton, New Jersey.

2. Jensen OM, Parkin DM. Cancer Registration: Principles and Methods. International Agency for Research on Cancer, Lyon 1991: 78-81.

3. Wojciechowska U, Didkowska J. Zachorowania i zgony na nowotwory złośliwe w Polsce. Krajowy Rejestr Nowotworów, Centrum Onkologii - Instytut im. Marii Skłodowskiej-Curie. http://onkologia org pl/raporty/ (2016.08.01).

4. Coyte A, Morrison DS, McLoone P. Second primary cancer risk - the impact of applying different definitions of multiple primaries: results from a retrospective population-based cancer registry study. BMC Cancer. 2014; 14: 272, doi: 10.1186/1471-2407-14-272, indexed in Pubmed: 24742063.

5. Ishimori T, Patel PV, Wahl RL. Detection of unexpected additional primary malignancies with PET/CT. J Nucl Med. 2005; 46(5): 752-757, indexed in Pubmed: 15872346.

6. Tong SY, Lee YS, Park JS, et al. Clinical analysis of synchronous primary neoplasms of the female reproductive tract. Eur J Obstet Gynecol Reprod Biol. 2008; 136(1): 78-82, doi: 10.1016/j.ejogrb.2006.09.010, indexed in Pubmed: 17049712.

7. Takeda T, Sagae S, Koizumi M, et al. Multiple primary malignancies in patients with gynecologic cancer. Int J Gynecol Cancer. 1995; 5(1): 34-39, indexed in Pubmed: 11578450.

8. Eser S, Gulhan I, Özdemir R, et al. Synchronous primary cancers of the female reproductive tract in Turkish women. Asian Pac J Cancer Prev. 2011; 12(4): 857-859, indexed in Pubmed: 21790215.

9. Babacan NA, Aksoy S, Cetin B, et al. Multiple primary malignant neoplasms: multi-center results from Turkey. J BUON. 2012; 17(4): 770-775, indexed in Pubmed: 23335539.

10. Kornafel J, Mądry R. Nowotwory kobiecego układu płciowego. In: Krzakowski M, Warzocha K. ed. Zalecenia postępowania diagnostyczno-terapeutycznego w nowotworach złośliwych. Via Medica, Gdańsk 2013: 265-317.

11. Jassem J, Krzakowski M. Rak piersi. In: Krzakowski M, Warzocha K. ed Zalecenia postępowania diagnostyczno-terapeutycznego w nowotworach złośliwych. Via Medica, Gdańsk 2013: 211-264.

12. Kawecki A, Nawrocki S. Nowotwory nabłonkowe narządów głowy i szyi. In: Krzakowski M, Warzocha K. ed. Zalecenia postępowania diagnostyczno-terapeutycznego w nowotworach złośliwych. Via Medica, Gdańsk 2013: 1-32.

13. Kleinerman RA, Kosary C, Hildesheim A. New Malignancies Following Cancer of the Cervix Uteri, Vagina, and Vulva. In: Curtis RE, Freedman DM, Ron E, Ries LAG, Hacker DG, Edwards BK, Tucker MA, Fraumeni JF Jr. (eds). New Malignancies Among Cancer Survivors: SEER Cancer Registries, 1973-2000. National Cancer Institute, NIH Publ. No. 05-5302. Bethesda, MD, 2006, 207-229.

14. Lin AY, LuT, Gomez SL. Synchronous cancers: An analysis of SEER registry from 1973 to 2003. J Clin Oncol. 2010; 28(15_suppl): e12018-e12018, doi: 10.1200/jco.2010.28.15_suppl.e12018.

15. Agrawal R. Synchronous dual malignancy: successfully treated cases. J Cancer Res Ther. 2007; 3(3): 153-156, indexed in Pubmed: 18079578.

16. Kuncman $€$, Danielska J, Kuncman W, et al. [Synchronous occurrence of four malignancies in a 55-year-old woman with uterine cervical cancer. Case report and review of literature]. Ginekol Pol. 2016; 87(4): 314-317, doi: 10.17772/gp/62978, indexed in Pubmed: 27321106.

17. Świątoniowski G, Brużewicz S, KłaniewskiT. Radical treatment of patient with three independent malignancies. Onkol Prakt Klin. 2008; 4: 107-109.

18. Atasever M, Yilmaz B, Dilek G, et al. Synchronous primary carcinoma in 5 different organs of a female genital tract: an unusual case and review of the literature. Int J Gynecol Cancer. 2009; 19(4): 802-807, doi: 10.1111/IGC.0b013e3181a39b95, indexed in Pubmed: 19509592. 